This is the version of the article accepted for publication in Geopolitics published by Taylor \& Francis: https://www.tandfonline.com/toc/fgeo20/current

Accepted version downloaded from SOAS Research Online: http://eprints.soas.ac.uk/29943

\title{
Pashto Border Literature as Geopolitical Knowledge
}

\section{James Caron}

School of History, Religions, and Philosophies, SOAS University of London, London, UK

Thornhaugh Street, Russell Square

London WC1H 0XG

james.caron@soas.ac.uk 


\section{Pashto Border Literature as Geopolitical Knowledge}

In this article I read a selection of Pashto literatures as critical thought about geopolitics. Drawing on Michael Shapiro's concept of aesthetic subjects, as well as on border theory, I argue that the authors, the content, and the literary networks of these works all comment on global relations of power, ranging from the local bordering effects of geopolitics, to systems of knowledge embedded in the spatiality and temporality of empire. I argue that past and current imperial processes have led to fragmenting effects in Afghan society, and literature both reflects and analyzes this. Beyond that, I argue - through the examples of authors' lives as well as their work - that literary activity in Pashto has actively negotiated such processes throughout its history, and offers strategies for countervailing notions of global connectivity in action as well as thought. The decentralized and multiperspective images of life in these works sit in counterpoint not only to the systems-oriented views that drive military and other policy in Afghanistan during the ongoing US moment, but also to universalist perspectives upon which disciplines like world history and geopolitics traditionally rely. Additionally, though, Pashto literary networks themselves also produce alternative structures. This contributes to the aesthetic turn in IR by arguing that it is not only the aesthetic vision in works that challenges dominant knowledge; the shape of the Pashto literary formation itself, organic with its content, is an alternate form of knowledge-in-practice about the contemporary world.

\section{Introduction}

In the first decades of the twenty-first century, all the world is living through a watershed moment in the understanding of societies. In this, Afghanistan is a stage for innovation. Since the War on Terror era began, the most globally influential body of knowledge about Afghanistan has involved ever less conversation with Afghans, and ever more a conception of people as 'human terrain' that can be modeled by systemsengineering specialists, to represent reality more faithfully than people themselves can narrate it. In one multimillion dollar project that emerged on the back of the Human Terrain Systems program of military-embedded ethnographers, the data that social 
scientists collected was combined with physical and environmental data to create social simulations of clusters of villages (Stockman 2010), able to predict social trends better than any individual in that society itself would, for the purpose of forming military policy.

This echoes, builds on, and even outstrips the processes of the formations of colonial knowledge that Jon Anderson (1992), among others, describes: processes that were part both of British imperial management of the Afghan border region, and of subsequent writing about that region. Dan McQuillan (2018), for instance, notes how the epistemology of 'machinic Neoplatonism' that undergirds such modeling is generally still susceptible to the same coloniality of power that is embedded in older imperial knowledge processes. Taking both cases together maps a trajectory in which Afghans have been placed as ever more peripheral to knowledge of their own modern world. Ever more provincialized visions of Afghanistan and Afghans are locked into the bounded situatedness - a dynamic objectification, but an objectification —of systemic models that help determine policy. Enormous amounts of aggregated fact-fragments produced from such projects, embedded in metadata that are used to produce bounded data ontologies, were released to academics and the public at large from the US military's SIPRNet databases as part of the 2010 Wikileaks affair. Some future history-writers may see this archive as an unparalleled windfall. For others, either history or geopolitical thinking that relies on this sort of archive might represent a nightmare of quantitative dehumanization, the worst excesses of an approach to humans that reduces some to (provincialized) terrain that (universalized) others write themselves onto. In contrast to either, the content of the literature I read in this article, and the experiences of their authors, both register a 
tentative imagination of how we may reconstitute better futures from the shifting relationships between ever-evolving individuals in the midst of dystopia.

In arguing this I take a cue from the same thing I describe: the critical border vision of Pashto literary knowledge, which is enacted in the content of its art, and in the social history of its literary formation and the networks that it moves through. I argue that intellectual production from Afghanistan, figured as what I describe presently as a 'global borderland', challenges dominant visions of what knowledge of the world-at-large can be. In place of a state-centric will to fixity, to monopolizing the truth of any historical encounter by placing it in a matrix of plural but limited meanings and potentialities, I show, Pashto literature often focuses on the openness and indeterminacies of such encounters - in this case, those of violent bordering and territorialization amid decades of war. This vision is akin to Walter Benjamin's (1968) secular-messianic ethics of recovering the 'exiled' potentialities of history (Ware 2004), ones effaced by the state's repertories of violence that it uses to constitute itself, by its technologies of destruction of the past and present. By recovering past potentialities, a strong trend in Pashto literary production focuses on future redemption. It does so, I will show, through producing what Foucault $(1986,24)$ calls 'heterotopias': “something like countersites, a kind of effectively enacted utopia in which the real sites ... are simultaneously represented, contested, and inverted," and by stringing them together into new patchwork cartographies. In this, it is both similar to, and apposite to, the superficially dynamic knowledge represented by big data, as well as opposed to the objectifying fixity in modes of historiography that are inflected by state or colonial power. 
There are sociological factors that contribute to this ethos. The historically subordinate position of Pashto literature contrasts with the bureaucratically and hegemonically dominant languages of Persian, Urdu, and English; which even Pashtuns have historically used to project objectifying discourses of power and civilization when they have occupied spaces of authority. This has meant that operating in Pashto literature — since at least the sixteenth century - involves self-conscious participation in a linguistic zone at the moral and aesthetic fringes of empire. This has often been the case in the social space created by poetic networks, but in the late twentieth century prose has been interlinked to this realm as well. And, as we will see in the works discussed here, this has consistently involved reflexive attention, in literary works, to 'Pashto literature' as a process: one that interlinks multiple aesthetic worlds outside of, and arguing against, the fixity that imperial processes of bordering and ordering seek to impose. Thus the Pashto case, like other borderland literatures, contributes to the 'aesthetic turn' in IR by presenting a case in which the sociological conditions of aesthetic production are themselves a form of enacted knowledge, inseparable from that which they convey in their content. ${ }^{1}$

In order to argue all this, in this article I read Pashto literature composed since 2000 - short stories, poems, and a novella. These literary works, their authors, and their networks critically negotiate the many ways in which Afghanistan has been created as what I provisionally call a 'global borderland'; and with this term, I point to a specific kind of long-term history. The regions centered on the Hindu Kush were textured in antiquity and in the early modern period by Persian and Indian influence; and then colonized in the modern period by British empire. In all these periods, imperial political- 
economic and sociocultural hierarchies built centralizing authority structures that pulled regional social networks — state institutions, trading solidarities, tribes, religious networks - in various disparate directions, making them at least as responsive to their ties beyond any local horizon as they were to each other locally, and creating new 'borders' between them in that way. The mid and late twentieth century brought Eastern European, Soviet, and US influence, first through development aid and later through military intervention. This created borders between multiple outward-looking factions in the government and in society. Moreover, in the US case, military intervention was indirect, exerted through local powers including Pakistan's intelligence services and its religious parties. This, along with official and private Saudi partnership in the covert war, resulted in reformulations of Islamic authority via mujahid and talib factions that reordered and segregated Afghan life into yet more hierarchic factions, as much as direct imperial control has done. On top of all this sits, now, a direct overlay of neoliberal restructuring of social relations. This was brought first by the influx since the 1990s of western NGOs in Afghanistan and their increasingly central role in managing social, especially including under the Taliban. It was accelerated further by the occupation of Afghanistan amid the US-led intervention that removed the Taliban from power.

But finally: shaped by, yet cutting across, all the above are the worlds of Afghan mobility: global and local, physical and aesthetic. The energy of migrant Afghans negotiating plural worlds, and the social connectivities that this creates in Afghanistan and beyond its borders, have been both integral to and marginal to empire and colonial modernity (Crews 2015; also Digby 1965, Green 2008, Nichols 2008). This has always been a counterpoint to imperial fragmentations, even if this counterpoint enjoys less 
global visibility. And it is this bottom-up globality in which the stories of our authors' lives and their characters' lives are situated. As I argue in the next section and throughout, using Michael J. Shapiro's (2012) concept of 'aesthetic subjects', these two kinds of stories are not separable.

\section{Aesthetic Subjects and History in a Global Borderland}

The work of Pashto short story author 'Abd al-Wakil Sulamal Shinwari and his biography, together, are an entryway into these themes. Sulamal was born in the upland Haska Mayna district, in Nangarhar Province which borders on Pakistan. Faced with a choice between military conscription or Soviet education in service to the Afghan state, he obtained a Masters' degree in military pedagogy in Minsk before returning to work in the Afghan Ministry of Defense. A few years after the fall of the People's Democratic Party of Afghanistan [PDPA], he emigrated to Peshawar where he worked as a journalist with the Writers' Union of Free Afghanistan [WUFA]. This body was originally created as a non-partisan patronage alternative both to the PDPA's circles of state-sponsored intellectuals, and to the militant mujahidin factions' patronage networks of audio-cassette poetry and written literature — networks that grew into durable transnational politicaleconomic and cultural hierarchies during the period that they were funded and even cultivated by the intelligence services of the US, Saudi Arabia, and Pakistan. WUFA eventually brought together authors who emerged from the communist writers' unions, from the mujahidin, and from among expatriate intellectuals who were formerly tied to older state institutions and who now worked with western news and intelligence services. 
As literary scholar Zarin Anzor (1993) describes, their solidarity recombined elements from all these networks even as that solidarity, and the new physical and social space it created, was a response to these authors' discontent with those networks.

In short the WUFA's, and Sulamal's, creation of networks in such spaces is an illustration of the border processes I introduced above, and his life after that traces more than one of the global spaces to which local ones were tied. After working with the WUFA for a number of years but searching for stable employment to no avail, Sulamal left Peshawar for further afield, spending many years in Bratislava until he then moved to London. Amid all this, as we will see soon, Sulamal's work too stands in contrast to the literatures colonized either by the communist PDPA or by the mujahidin factions that asserted forms of local territorialization and bordering, both social and geographic.

I begin with Sulamal's biography because it is in keeping with my argument that the literary formation and the contents of Pashto production are two parts of the same knowledge form: that is, the characters in these stories and the lives of their authors are inseparable. Following the work of Michael J. Shapiro, I see these literary authors, as well as the characters they enact, as 'aesthetic subjects' who operate in realms that may include, but subsume and exceed, rational argument, and who mobilize alternatives to dominant frames of knowledge through aesthetic work (Shapiro 2012; Opondo and Shapiro, eds. 2012). Just as Sulamal's life moves across geopolitical territory in macrocosm, and across various forming-and-disintegrating literary institutions in microcosm, Sulamal's characters both inhabit and describe extreme plurality in a set of societies configured by empire as a global borderland. They also critically theorize, through narrative, the processes of fragmentation that they describe; and provide alternate 
imaginations. Before fleshing this out, though, I should pull back and read a few narratives that focus on the production of borders-geopolitical, geographical, and psychosocial - in Afghanistan. I will return to the issue of alternate imaginations, and the refiguring of bordering as potentiality rather than fixed event, in subsequent sections.

Sulamal's story 'The Old Fort' is a good example of a narrative of bordering, as well as an exploration of the limits of its subversion. ${ }^{2}$ Before the eyes of our narrator, a recently returned expatriate, the inhabitants of his ancestral village uproot all of its architecture in an attempt to purify its inauspicious past by erasing all memory of their "ignominious cousins": those who had embraced the communist party. As his own family joins in, the narrator appears to be the only one who notices that they are destroying the very structures they live in. While the narrator has not been affected by a decade of ideological change, due to his absence, this has fragmented his perspective away from that of his family. He leaves, disillusioned. The story then moves forward in time. The narrator returns years later and finds the entire village living in tents. New colored banners demarcate new, fragmented rural geographies that restrict movement.

The narrator's experience serves as a reminder that human mobility and ties of kinship constantly place histories of memory in tense discussion with histories of destruction that lead to forgetting. The point is not just the fragmentation of locality, but fragmentation of past and present. Engagement with even older pasts, marginal but still existing, draws the Pashto reader into the same role as the narrator's - the individual who remembers - and places the reader in a position of empathy with yet other aesthetic subjects. That is, as the dismantling of social life proceeds apace, the village's past lives, existing in traces as domestic utensils and mysterious Hindu and Buddhist effigies buried 
in the soil, no longer abide in anyone's memory except that of the very poor, those with no stake in the local partisan factions created by transnational militancy. Other villagers excavate this once-shared past as objectified artifacts: theartifacts represent idolatry to them but are marketable to foreign collectors, and will hence further fund local militarization. As he walks on past this scene, the narrator leaves the village, resolving never to return.

The geopolitical dimension here is unsaid, but it is understood to its readers: the spatiality of the present is colonized in part through fragmentation of the past, and this is not only a local process. The 1990s mujahidin era, to which this story refers, came after successive waves of influence from ever-farther sources: foreign investment from the Eastern Bloc (1960s) followed by local communist revolution and then direct Soviet intervention (1978-1989). This was succeeded by Islamist counterrevolution that brought global funding through the militant organizations based in Pakistan, each of which developed its own cultural programs alongside its own transnational political and economic redistribution structures. When the international funding dried up, leaders throughout the hierarchies of each faction began cannibalizing its own client base for resources, fostering civil war on highly local levels. The various elements of the story give a trajectory of ever-greater spatial fragmentation when seen from the perspective of rural life: a transregional past reflected in the pre-Islamic artifacts; a national-state constructed amid early Cold War superpower rivalry and represented by the structures built by the "ignominious cousins"; a postnational, presentist wartime imagination of space in which even neighborhoods have borders between and within them. The deterritorial subject of the narrator, existing in global space, is as powerless as the reader 
is to address this local fragmentation, in the face of the much more dominant global forces that drive local territory-creation.

Sulamal's even darker farce 'Fifty Million' (Sulamal 2010) comments on a new era of globalized fragmentations that run even deeper: rewriting the meaning given to bodies and their most intimate relationships, those of kinship. It fixates on the trope of an influx of naked cash as a metonym to explore one aspect of neoliberalized society during military occupation. The main character "Jandad" rethinks his circumstances upon hearing a radio announcement: a bounty of fifty million dollars for Osama bin Laden, dead or alive. His once-jovial nature fades as he joins the Taliban in an increasingly obsessive and desperate search for the man. Jandad's self-respect as a patriotic mujahidin commander, and the propertied husband of two women, is rewritten in starkly monetized terms as penury as he is confronted by new standards of wealth. His comfortable life now feels paltry...perhaps, although the story is not explicit on this point, when compared to the lives of those few in Kabul with access to internationalized corridors of power in neoliberal-era Afghanistan, those who can comfortably conceive of what fifty million dollars would actually mean in practice?

The geography of Afghanistan is remapped as Jandad wanders across it, objectified and transformed into a list of the places he has searched for, and failed to locate, bin Laden. Eventually, after years of failing to find fifty million dollars hiding "under any rock or in any tunnel", Jandad returns home. He and his young wife hatch a plot, as they stare at the walls in silence: is not the picture hanging there, the picture of Jandad's beloved, younger, full-blooded, and only brother "Zardad," the spitting image of bin Laden? American policy in this scenario drives people in the Afghan landscape to 
think of themselves and others in terms of categories — 'terrorist', 'collaborator', 'commodity' or 'irrelevant' — by attaching monetary value to these categories, even though in their agentive maneuvering they are required to inhabit more than one category at once. Like the landscape of Afghanistan itself, Zardad's body is objectified and rewritten in Jandad's mind as the potentiality of fifty million dollars. But Zardad's body fails to live up to his name just as surely as Jandad's actions fail to live up to his: Jandad ("Gift of Life") slays his brother and brings his head to an American outpost, while the grisly remains of Zardad ("Gift of Gold") inevitably fail the test of identification and fetch a mere pittance, a token payout of $\$ 35,000$ in ironic recognition of Jandad's good intentions toward US policy objectives.

These are only two among many of Sulamal's short stories, published in at least six collections since the 1990s. Now at this point, rather than focusing on individual stories, it might be good to consider the overall sort of picture that emerges from stringing together a series of such individual images, as Sulamal's collections and his combined oeuvre do. Sulamal's individual vignettes do not approach a unified Afghan history of the recent world in their scope; but this is part of the point. Pashto literary production illustrate a need to think of 'the whole' in different terms altogether, as a set of relative and discrete, but interlinked, perspectives that form nodes in a 'multiverse'. As Vinay Lal (2011) notes, histories of globalized cross-cultural encounters look quite different on the micro-level when it is the provincialized and situated, rather than universalized, subject who is the world historian. This is true when imagining fragmentations, but it is also true when imagining recompositions from the local perspective of nodes in a network, rather than from the top-down survey vision of 
colonial forms of knowledge. And as the poet, theorist, and activist Gloria Anzaldúa highlights, the act of preserving and negotiating such nodes and their situated rather than universal forms of knowledge, and then forging bridges between them: this is both an epistemological act and an ethical-normative one (Anzaldúa 1987, esp. Ch. 7). In the next section, then, I move on to introduce works that not only pessimistically interrogate processes of fragmentation, but also ask about possible recompositions of life across and outside of those fragments. As we will see, some of these works directly theorize this point in abstraction. Others, to which I turn first in the next section, dramatize reconstitutions of space intuitively, by shifting their narration to subjects who build the realm, as Michel de Certeau would put it, of the 'tactical' everyday, rather than negotiating the 'strategic' level of dominant regional and global actors (Certeau 1984).

\section{Negotiating Fragments to Imagine a Multiperspective World}

A longer work by Muhammadajan Yar, a novella titled 'An Eyewitness Account of the Dasht-i Layli', attempts at linking the remapping of one experienced locality's present to a long-term history of increasingly global interactions (Yar 2004). The novella traces the fictitious eyewitness account of an unnamed farmer who was caught in a Northern Alliance sweep through Pashtun villages near the town of Sheberghan, close to the Turkmenistan border, after the 2001 fall of the Taliban in Kunduz; detained with other non-combatant Pashtuns alongside Taliban POWs; loaded in the hot sun into a blistering metal shipping container with them, and transported to the Dasht-i Layli desert for execution. It is framed as the account of this man after he miraculously escaped the scene of the atrocities, set off through the hinterland, eventually reached his family's 
ancestral homeland in Pashtun-majority Nangrahar province, and met the author in a small store in Jalalabad. But this trauma is only the backdrop for an exploration of the mutability of local historical experience, in the face of geopolitical change.

The story begins with a recitation of the narrator's historical memory: his father had once claimed that Pashtuns originally came to "Turkistan" in the 1930s under a state policy designed to make the north productive, and to link it to the rest of the country as Afghanistan consolidated its internal geography as an independent state. The steppes had been a wasteland, the narrator was told; and once these Pashtun pioneers had created settlements, building agrarian productivity through painstaking labor, then "Tajiks, Uzbeks, and a few Turkmens" also started settling in the region. Roads and infrastructure were built, consolidating a national domestic geography. Back-and-forth flows of people increased, further consolidating it. Things were fine, our protagonist recalls, up until Daud Khan's 1973 coup. From that point, "each day was worse than the last". The Taliban were the worst, he says. They rewrote history and cultural heritage, effacing the past. And, they inadvertently heralded a new era of invasive globalization: they "brought the world's attention to Afghanistan" such that the US and the UK were "driven to intervene and take the country from them". As American B-52s bombed Taliban positions, we hear, local Northern Alliance commanders took the opportunity to mislead their credulous new US allies into destroying innocent Pashtun villages, and conducted a new series of anti-Pashtun pogroms themselves also under cover of war. At one point the protagonist realizes (as his Turkic and Tajik neighbors had presumably long known) that one can be suddenly deprived of one's subject position in the face of externally-created identities, encouraged by geopolitical forces. As he, a Pashtun farmer, is captured by 
Northern Alliance forces, he pleads with an adolescent gunman that he has done nothing. He is beaten and told, in Persian, "Be silent; you're all savage, culture-less Taliban!" (Yar 2004, 24).

Now, there is more than one way to read this narrative. The story is in Pashto, which marks it as sectional from the outset in any reading oriented toward the breakdown of a nation-state consciousness, in a country where Persian is the lingua franca and generally seen as a language of high culture. And this particular massacre at Dasht-i Layli, one of a series of them, is an event that has been used by Pashtun political groups in a way that echoes Veena Das's words from a different context. That is, a focus on this particular trauma has often functioned in Afghan public discourse as a way to "open up suspect spaces in which stories of suffering are deployed in the dividing practices of separating 'innocent' victims from 'guilty' ones” (Das 2003, 297). So, the historical narration in this novella might provide an opportunity to reiterate older histories of innocence that legitimate resentments in the present, thereby participating in a spiral of communitarian violence and revenge. In my reading, though, this well-worn narration is supplied at the outset in order be interrogated later. It becomes unsustainable through the course of the novella, and rather than this being a story that opens up wider fractures, it becomes a story about the possibilities and limits of overcoming them. The violence visited on the narrator and his community occupies less than half the book, while the remainder traces encounters with members of other ethnic communities as the narrator flees.

Staggering from settlement to settlement, the narrator encounters numerous other individuals including a powerful Turkmen $a r b a b$ and a Tajik Jami'at militia commander. 
They help him as individuals, even as the larger identity politics taking shape in the region constrain them to tell him why, historically, the ethnic cleansing of the north must happen; why he must continue fleeing. For the first time he encounters alternate pasts, their pasts, which sound less like the history he had been told, and more like settler colonialism by Pashtuns onto a preexisting Turkic population. History in this region has long been fragmented under the weight of transregional power, even if the relatively privileged place of Pashtuns in official-nationalist constructions of the north has blinded him to that fact. And new locally-dominant pasts are forming as older hegemonies are dismantled, even though those pasts are based on the same set of events. But this is not the extent of the story. When its characters are forced to negotiate with each other in concrete transactions, rather than abstract collective ones, new possibilities emerge from the empathy that can result from displacement of absolute narratives. He would not have escaped to safety without these individuals' help: giving him lodging for a night; telling him who to avoid, and why. In such contingent, face-to-face situations, individuals may potentially address others as individuals; and unique relationships of selflessness, rather than identity boundaries, can be negotiated in real-time. This story is history as potentiality, built out of new recompositions of past ways of being, knowing, and feeling. This is so, even as these contingent and localized relationships are ephemeral.

Yet, not all such transactions are necessarily so fleeting. Their effects accumulate over time, in borderland space. Let us return to Sulamal. While much more allegorical, his story 'The Village and the Bus', like Muhammadajan Yar's novella, is a stage for both fragmentation and new recomposition. At its base, it narrates a crime of passion. A bus arrives in an isolated and starving village. It has temporarily broken down but it is 
part of a route that has finally relinked this unfortunate settlement to its more prosperous neighbors "in the next valley over the mountains". That is, the story describes the local meeting of two returnees arriving on the bus, one who had relocated to Europe and one who was raised over the mountains in Pakistan, both vying for ideological influence over the future of "the village": a localized backdrop for the story, and a metonym for Afghanistan. At the same time the bus is an allegorical stand-in for the Afghan state. The first newcomer, a westernized and scarcely-recognizable native son who was born in the village, argues for a hasty blanket repudiation of the bus's drivers, whom he sees as hopelessly traditional and inept, the very reason that the bus has broken down in the first place. He gets into an argument with, and is soon slain by, the second newcomer: a hotheaded young rifleman, one who was born and raised just on the other side of the mountain and who is nativist in his ideology despite never having seen the village itself, and who is rather more compassionate toward the drivers than the first newcomer is.

Importantly, though, the murder is not the end of the story. As a shocked village discusses what happened, each person produces a phrase-length commentary on the events. Their discrete and even conflicting narrations merge into consensus: they combine into a folkloric song of self-criticism that the entire village participates in. The story is a powerful image of new metanarratives in formation, and of how those metanarratives are internalized while they are produced, by individuals in the community, through the act of participative literary exchange. As in 'The Old Fort' and in Yar's novella about Dasht-i Layli, these perspectives consolidate themselves and exclude older, prior metanarratives in the process. But in this case, the global cross-cultural interaction is not an omniscient narrator surveying the rise of new narratives amid local 
fragmentation, as in 'The Old Fort'. Instead, the meeting of two differently-globalized intellectuals is what produces violent conflict. This both obliges, and creates opportunity for, local collaboration at one node of a network-in-formation to build countering solidarities of a qualitatively different sort. Here the newly dominant perspective, the song of self-criticism among villagers situated on the bus route, bears the suggestion that it may be less stabilized and fixed due to its open, participative nature. And yet this exists in durable literary space: it is not only an issue of fleeting individual transactions, as in Muhammadajan Yar's narrative. Here, constantly emergent, collaborative self-reflection on the divided present may optimistically invite the possibility of a more humane future at the same time as older geographies, forgotten but persisting as metaphorical bus routes, are regenerated through new activity. The song may seem to be an odd anticlimax if we read it as a story about murder. But if we read attuned to decolonial space-time, the song is itself the climax to a different story, bearing an oblique suggestion to which I turn now. The reflexivity of a transregional literary formation, along with the basic fact of its existence, is part of what stitches together fragmented networks into new, and lessviolent, kinds of cartographies.

\section{Border Literature as Theory-in-Practice}

In looking at ways that older fragmented space-time can be recalled by aesthetic subjects in Pashto literary production, and new, less-violent cartographies can be constructed out of the ruins of the old, poetry is at least as interesting as narrative prose. Take for example a cycle of long poems, published in the 2000 collection Da Xaperay Warghoway by poet Pir Muhammad Karwan, about war, dislocation, and shifts in 
aesthetic knowledge. The entire poem cycle is a disjointed series of images, impressions, and vignettes written from a variety of loosely autobiographical subject positions, all linked at various points by the voice of 'The Wilderness' writing letters to Karwan. He is a boy who used to hold conversations with a speaking mountainscape that knew no borders; a youth who worked in cross-border camel caravans smuggling weapons in the 1980s; a man who became a transnational poet based in Peshawar and Kabul and who founded one of Afghanistan's premier literary salons. Taken as a whole, the cycle builds a kaleidoscopic impression of fragmenting time, space, and ontology within a single subject; but these fragments are productively reassembled into 'new life' through the life of its protagonist. Karwan's organization, the Afghan Adabi Bahir, now includes not only live meetings in Kabul but also radio call-in programs that attract participation from men and women, urban and rural, across Afghanistan. Thus Karwan linked oral, literate, and electronic networks of Pashto literature through his personal subject-formation across domains, through his social activities that place his art in concrete social space and build space for others' as well, and through art that comments on these boundary crossings in its content.

Leading into the excerpt below from this cycle, Karwan has already described a recent encounter with his publisher in Pakistan who asked him to produce marketoriented love songs in place of his earlier preoccupation with trauma. He then has moved on to recall a much earlier encounter in his childhood with the oral poetic world: an impromptu performance by a party of ecstatic mujahidin youth in the Khost mountains that drew on much deeper sedimentations of affects of love and concern, in a traditional micro-genre, the tappa, that is in part defined by such affects. After a description of the 
mujahidin party's subsequent clifftop encounter with a Soviet jet, Karwan then pulls back from these disjointed vignettes; and in the personified voice of the Khost border wilderness, he addresses both reader and poetic subject directly, in order to reorient the reader's attention to a wider conceptual view of social and intellectual life in the globalized conflict that gripped his region. Creating a metaphor for social and cultural fragmentations and recombinations amid war, the sentient landscape itself describes fragments of abstract space forming constellations, falling to earth, and giving rise to new interactions. The Forest-as-Storyteller writes, in a letter to Karwan:

In the middle of this story / There are many deserts, mountains, crags / Arrows ripped from chests / Arms chopped off by swords / It's very reckless / Fighting with dragons / In the middle part, houses turn into cemeteries / Emptying out filled beds / We'll leave aside this middle part of the story / By God, it gets really bitter / So anyway, it's hardly even twilight / Not yet fully night / Droplets of the dragon's venom / Will form themselves out of white stars / And you'll see its teeth / Made from some other stars / All the wounds of the young-men / Will form themselves out of golden stars / You'll see all these stars / Fighting with each other / Some will flee their orbits / Some will fall to earth / They'll smash on the cliffs / They'll fall into the springs / And there, from inside the two halves of their husks / As their kernels swell up, new life will emerge. (Karwan 2000, 3739)

Returning from the sensory world of nature and war violence to the affective and cognitive worlds of literature in a later poem in the cycle, 'Give them a tongue with tappas', Karwan completes the circle and unifies experiential knowledge of a devastated wartime environment to human literary interaction, in recompositions of new meaning. The Poet and The Forest collaborate to use the skins of predatory wolves, and the discarded munitions casings that litter and poison the forest, to build drums. The Poet and the Forest hope in turn that the act of repurposing these materials into musical instruments will neutralize the violence built into them. They hope that the drums will once again propel the songs, tappas, that mountain women improvise. These will then 
provide a new language by which entities who have not found a voice in the violent setting they find themselves in —-human and non-human entities alike—can conceptualize new modes of justice: incorporating to themselves the environmental and human devastation that they live in, and remaking it into new life. And in the poem completing the cycle, Karwan finally ties these regional impressions into an image of transnational literary networks through allusions to multiple current poets who do the same, and who thereby sustain transregional connectivities between environment, village, city, and wider worlds.

Karwan's folk-surreal style is distinctive in Pashto literature. But his juxtaposition of plural knowledges and aesthetic expression to describe processes of fission and recombination? This is not new and he does not claim so. Into his border spaces irrupt traces of prior interregional geographies, alive in the aesthetic subjects that gave them life. The aesthetic subject Karwan links print-sphere lyric in global circulation among Afghans into concrete performance by transborder itinerants. Those subjects in turn channel much older structures of feeling that pre-date any of the states or empires around them. The tappa, the two-line micro-genre that Karwan's mujahidin party sing and that reemerges to the sound of wolf-mortar drums later, is also a major, and highly formal, genre preserved in James Darmesteter's 1870s Pashto/French anthology Chants populaires des Afghans which, compiled as the British empire consolidated rule on the Afghan frontier, is our earliest comprehensive archive of Pashto folklore. Often composed impromptu as part of everyday interaction, Darmesteter's tappas circulated in piecemeal networks from Qandahar to Peshawar to South India with mobile traders and laborers and poets, cutting across the imperial and state bordering that was progressing 
even as Darmesteter was collecting them. ${ }^{3}$ And other poems in that anthology, sung by the same mobile people, dramatize similar mobility in yet older settings. One is the qissa, a genre of ballad or verse romance, of Fateh Khan and Rabia: two lovers from the trading hub of Qandahar whose relationship, set in the sixteenth century, transgressed local patriarchal power. They rode off along with a retinue of friends into the Mughal heartlands to the east, enjoying success after success in a series of narrated episodes until their party was eventually defeated at the gates of the Delhi fort (Darmesteter 1888, 117). In this qissa, like so many other Pashto folk narratives that survive, the anti-structural desire of romantic love is mirrored in the act of overcoming fixed identities that were determined by imperial geography and lineage patriarchy.

There is a continuity between Karwan's contemporary folk surrealism and the fragments from earlier oral worlds that he incorporates into his work. Karwan's poem cycle, emerging as a fragmented qissa-autobiography of sorts, rewrites folk knowledge of body, place, and mobility into a story about the everyday perception of rupture and fragmentation. At the same time, tappas link deep-historical sedimentations of affect to contingent circumstances. The song that the village composes impromptu in Sulamal's short story 'The Village and the Bus' does something similar. These nested genrefragments are all separate, but they all emphasize transactions in everyday life that link across space and time to form a counterpoint to the violence of geopolitics. The genres are not the same either, but in each case, as they build webs from episodic fragments of experience, as subjects interact at the interstices of empire and across them, they create worlds that exceed imperial reach in space and time both. Moreover, like Karwan's 
poem cycle suggests, the long-term cumulative effect of this sort of activity has built it up as a reflexive approach to aesthetics and life alike.

\section{Conclusion: Afghan Knowledges of Globality; Alternatives to History}

In my reading of literary practice as critical thinking about geopolitics, I draw on themes from the work of the poet and literary theorist Heriberto Yépez, particularly " $\mathrm{La}$ frontera como falla" ("Borderland as Faultline"), as well as the work of the historian and anthropologist team Ben Hopkins and Magnus Marsden in their monograph Fragments of the Afghan Frontier. Yépez describes a 'border' as a non-concept; it is not a thing or a place, but rather a process in which loose 'systems' of politics, economy, and culture reach their limits, meet, and undermine and fracture each other's system-creating authority. But also, as Yépez argues in abstract and Marsden argues empirically, actors at the epicenters of these processes also reassemble the political-economic, cultural, and even psychosocial 'fragments' that result from them, in dialog with their own plural longterm histories. Such actors reassemble them into new worlds with their own senses of space and time and meaning, which can then potentially ripple back to start reshaping the more centralized systems around them. That is, even as they describe processes of 'bordering' and 'frontierization' and 'fragmentation', Yépez, and Hopkins and Marsden, also center the productive potential of both actors and modes of thought in such spaces. In so doing, they undermine the idea of borderlands as a periphery (or even, really, a 'borderland' or 'frontier' in most commonplace senses), and recenter such spaces' own salient space-time and their global importance. 
However, the works I discuss here already know all this, and they point to more still: as we have seen, they show that this kind of vision is not only an analysis, but leads to an ethics as well. In engaging these literary works we are faced with alternate visions of geopolitics and world history that are embodied in the lives of their authors as aesthetic subjects, as much as they are represented in the characters of the stories as aesthetic subjects. And in some, like Karwan's work, the literary formation itself even becomes a sort of aesthetic subject. Their experiences force us to rethink spatiality and systems of knowledge, but also present us with an alternate politics of temporality and the nature of events. The stories and poems introduced in this essay together revive older spatialities and alert us that similar processes of border living are ongoing now in global space, to those that have been going on for centuries. At the same time, narratives of disassembling and reconstituting relationships from contingent events are both the inheritance of a long-term history of the same, and a practice aimed at the future. I discuss these points, and the relationships between these narratives and the world, in this concluding section, before moving on to the points that I began with: literary activity in a 'global borderland' poses a countering approach to knowledge of geopolitics through aesthetics; this is related both to the dramatic content of the work and the sociological conditions it emerges in; and this is not an imagination of alternate worlds, but an enaction of them as well.

I read the works above as examples of a particular fiction genre, one sometimes labeled 'historiographic metafiction' (Walsh 2007): work that, while creating narratives, itself meditates on the process through which narratives are created. And, this has a distinct politics to it in this context. Sulamal and Yar are expatriate writers and migration 
has informed their work. Karwan never left Afghanistan, yet he draws abstract theory from the fact that migrant subjects and plural local ones - both in the literary formation and in everyday life — are not separable, in a transregional society that has been configured as a 'global borderland' but that has pushed back against this configuration constantly. In their destabilization of historical facts, as well as in the fluctuating spatial awarenesses to which they devote such attention, all these authors place an emphasis on how everyday yet global space-time beyond empire can be, and is, created. Theirs is a combined social and aesthetic practice that negotiates bordering, and that reconstitutes new formations out of the fragments that result from it. After a mobile society was encapsulated by British imperialism, the brief interlude of a territorial Afghan nationstate in the mid twentieth century meant that the sheer scale of new dislocations in the late twentieth century was shocking yet familiar for many Afghan Pashtuns in particular. This cumulative history—of mobility, then hierarchic centralization, and then mobility again - appears to have fostered a polycentered, subaltern globality in contemporary Pashto literature that reflects a broader experienced truth. Sulamal's vignettes, taken together, reflect a greater degree of decentralization of perspective, allowing him to draw a broader picture in aggregate without any single prognosis. Meanwhile, Yar draws one particular Afghan history of the world in greater depth, to maintain hope in the face of trauma, with his idea of reconstituting more humane relationships from the rubble of competing histories. So does Karwan. All three focus on an aesthetic of constantly fragmenting and reconstituting knowledge; all focus on the formation of aesthetic subjects on the shifting and contingent level of the everyday even as they comment on this as a long-term historical process too. None of these authors are uncritical of the 
possibilities for new violence that emerge from these moments. But the key point is the maintaining of open space in all its ambiguous potential for subjects to constitute each other outside of globally-dominant power relations, or the local manifestations of geopolitics, and to build constantly new forms of life on that intersubjective level.

In these works, it is the authors' experienced absence of the fixity of either imperial or nationalist perspectives, in everyday subjective life amid war and migration, that is itself ultimately the key point about 'what happened'. This absence is an opportunity: equally a concern of these authors is the repeated constraint over time that the crystallizing facts of dominant histories place on potentialities for subjects as well as for better collective futures. Stories like Muhammadajan Yar's reflect on the way that memory of the past, disassembled and reconstituted in erratic and unpredictable ways, can be a quasi-political, or alterpolitical, strategy that is useful for the future instead. At the same time, as both Karwan the poet and Sulamal the prose author describe, aesthetic activity and its networks in actual life have themselves frequently been a reflexive manifestation of that strategy. Literary interlinking of this sort escapes the forgetfulness of much geopolitical policy-thinking regarding longue-durée subaltern pasts- the geopolitical thinking that reduces Afghan society to its present, so as to manage it.

In sum, the literary activity I have described here is an actually-existing practice, a spatial and temporal reality, and a loose system of knowledge that comments on and refines both these things. It does so by recasting moments of bordering and violence, ever-pervasive in the historical geopolitical experience of Afghan life, as opportunities for a better set of futures. These futures exist as potentiality in the continuous contingency of reconnections between everyday subjects—subjects whose aesthetics of 
life blur binaries of past and present, individual and collective, 'fictional' and 'realworld'. In the context that opened this article, the rise of systems-engineering computational models that are based on a concept of humans as terrain, activity like this is the cumulative preservation of unpredictable life against the objectifying and foreclosing imagination of data.

It is no coincidence that in the current Pashto view from the border is a globality without a unified set of hierarchies; is phrased as quasi-allegorical fictive experience rather than fixed data; and focuses on radical contingency among aesthetic subjects as a tactic to undo the foreclosing effects that fixed answers about the past and the present can exert upon the future. The global borderland view from Pashto literary formations adds to the many-layered and polycentric approach to coloniality that scholars such as Madina Tlostanova, among others, have taken in the field of decolonial border thinking, and it certainly intervenes in Eurocentric visions of geopolitical space in international relations and world history, if readers choose to listen (Tlostanova 2013; Mignolo and Tlostanova 2006). But more generally, its nodal view is also the opposite of, as Heriberto Yépez puts it, the holistic "cybernetic" imagination - the systems-engineering perspective - in most important respects (Yépez 2007, 53).

This is important beyond Afghanistan, and argues for the salience of this mode of border knowledge to all readers here. What can Afghan literary knowledge share with the entire world, beyond an increased understanding of Afghan lives? That much would be sufficient, of course. However, we are all, worldwide, increasingly managed through data - in our scope for actions as people, and in our very constitution as beings fragmented into bundles of measureable characteristics. While this is a common claim at 
least as far back as Deleuze's (1992) "Postscript on the Societies of Control", it has become clear that there is an older colonial persistence here too. There is a difference between those whose personhood is constituted and managed in terms of potentialities like consumer choices, financial choices, medical information, and interaction with social media; and those subaltern populations in regions like Afghanistan whose digital personhood is constituted in large part by state suspicion and is fixed into bundles of very different characteristics by a military gaze. And yet this latter too has become a global technology of control, just as the disciplinary technology of the colonial prison was reimported to the nineteenth-century metropole. The same sort of systems modeling that was developed for deployment in Afghanistan has been applied to the study of neighborhoods and crime in the US, with predictive models that shape resource allocation and distribution of heavily militarized police forces and that seem to increase forms of insecurity and violence as a result. In a situation where Afghans are once again on the front lines of imperial experimentation in techniques of epistemic and physical violence, and in a world in which imperial experimentation at the borders has frequently returned to reshape societies worldwide, Afghan pasts provide a reflexive tradition of resistive ways of knowing and being. Thinking modern global history through Afghan literary eyes in particular - a vision centered on the creative and inherently unpredictable productivity of individual relationships in history and as history - may offer something to all the world in understanding and contesting violent forms of knowledge in the future. 
Acknowledgements: I would like to thank the anonymous reviewer for Geopolitics as well as Amna Chaudhry for their extensive engagement with earlier versions of this article, their careful reading of it, and their guidance in making it stronger.

\section{Endnotes:}

1 It is perhaps emblematic of this that Pashto literary culture itself is highly-developed, while a tradition critical commentary on it, including in Pashto, has been almost non-existent: I suggest one reason for this may be that much Pashto literary work, as this article highlights, already contains a comment on its own social existence as cultural-political and aesthetic intervention.

2 I should note that I have worked, in the case of Sulamal, from electronic files of these stories that the author himself provided me. In cases where I have not given citation information for individual stories, we have been unable to locate full bibliographic details; most of the older collections are not available outside South Asia.

3 Darmesteter (1888) discusses the provenance of his sources in passing, throughout various sections of this work. 
References:

Anderson, J. 1992. "Poetics and Politics in Ethnographic Texts: a View from the Colonial Ethnography of Afghanistan", in Writing the Social Text: Poetics and Politics in Social Science Discourse, ed. Richard Harvey Brown, 91-115. New York: Aldine de Gruyter.

Anzaldúa, G. 1987. Borderlands/La Frontera: the New Mestiza. San Francisco: Aunt Lute Books.

Anzor, Z. 1993. Da Sawr pa Trazhedey ke Farhang, Adabiyat, aw Azadey. Peshawar: Da Azad Afghanistan da Likwalo Tolana 1993.

Benjamin, W. 1968. "Theses on the Philosophy of History," in Illuminations: Essays and Reflections, trans. Harry Zohn, 253-264. New York: Schocken Books.

Caron, J. 2016. "Sufism and Liberation across the Indo-Afghan Border: 1880-1928" South Asian History and Culture 7(2): 135-154

de Certeau, Michel. 1984. The Practice of Everyday Life, trans. Steven Rendall. Berkeley: University of California Press.

Crews, Robert. 2015. Afghan Modern: the History of a Global Nation. Cambridge, MA: Harvard University Press.

Deleuze, G. 1992. "Postscript on the Societies of Control" October 59 (Winter): 3-7

Digby, S. 1965. "Dreams and Reminiscences of Dattu Sarvani: a Sixteenth Century IndoAfghan Soldier" Indian Economic and Social History Review 2: 52-98

Foucault, M. 1986. "Of Other Spaces” Diacritics 16: 22-27.

Mignolo, W. and M. Tlostanova. 2006. "Theorizing from Borders: shifting to Geo- and Body-Politics of Knowledge,” European Journal of Social Theory 9(2): 205-221

Green, N. 2008. "Tribe, Diaspora, and Sainthood in Afghan History" Journal of Asian Studies 67(1): 171-211.

Hopkins, B. D. and M. Marsden. 2012. Fragments of the Afghan Frontier. New York: Columbia University Press.

Lal, V. 2011. "World History and its Politics," Economic and Political Weekly XLVI(46): 40-47.

Lum, K. and W. Isaac. 2016. “To Predict and Serve?” Significance 13(5): 14-19 
McQuillan, D. 2018. "Data Science as Machinic Neoplatonism” Philosophy \& Technology 31(2): 253-272.

Nichols, R. 2008. A History of Pashtun Migration, 1775-2006. Karachi: Oxford University.

Opondo, S. O. and M. J. Shapiro, eds. 2012. The New Violent Cartography: Geo-analysis after the aesthetic turn. Abingdon: Routledge.

Shapiro, M. 2012. Studies in Trans-Disciplinary Method: After the Aesthetic Turn. Abingdon: Routledge.

Shinwari, Abdul Wakil Sulamal. 2010. Panzos Milyuna. Peshawar: Danish Tolana.

Stockman, F. 2016. "Knowing the Enemy, One Avatar at a Time” Boston Globe, May 30, 2010. online:

http://archive.boston.com/news/nation/washington/articles/2010/05/30/knowing_the_ene my_one_avatar_at_a_time/ accessed Dec. 122016.

Tlostanova, M. 2013. "Transcultural tricksters beyond time and space: decolonial chronotopes and border selves" Language. Philology. Culture 2(3): 9-31.

Walsh, R. 2007. The Rhetoric of Fictionality. Columbus: Ohio State University Press.

Ware, O. 2004. "Dialectic of the Past/Disjuncture of the Future: Derrida and Benjamin on the Concept of Messianism" Journal for Cultural and Religious Theory 5(2): 99-114.

Yar, M. 2004. Da Layli Dashta da Stargo Lidalai Hal. Peshawar: Da Pashtunkhwa da Pohane Dera.

Yépez, H. 2007. “La frontera como falla” Metapolítica 11(52): 49-53 